\title{
Physical and sensory properties of value added ready-to-eat (RTE) extruded snacks prepared from cereal-pulse blend
}

\author{
Poonam ${ }^{1}$, Grewal, R.B. ${ }^{2}$ and Hathan, B.S. ${ }^{1}$ \\ ${ }^{1}$ Department of Food Engineering and Technology, SLIET, Longowal -148106, Punjab \\ ${ }^{2}$ Center of Food Science and Technology, CCS HAU, Hisar -125004, Haryana
}

\begin{abstract}
The present study was carried out to utilize the cereal-pulse blend for preparation of ready-to-eat snacks using extrusion cooking. The cereal flours (wheat and maize) and different pulse flours (soybean and green gram) were assessed for proximate composition, total dietary fiber and minerals.For the preparation of control sample, the snacks were prepared from wheat flour-maize grits mix. The snacks prepared from wheat flour-maize grits mix in the ratio of 40:60 gave the highest expansion ratio. The effect of incorporation of different levels of different pulse flour on physical and sensory quality of extruded snacks was investigated. The physical properties namely expansion ratio, bulk density and hardness of the extruded snacks were analyzed. The snacks prepared from replacement of wheat-maize mix with $15 \%$ pulse flour had maximum sensory score and nutritional quality. It has been concluded that the pulses viz. soy bean and green gram can be utilized to prepare value added snacks by replacement of wheat-maize flour with pulses.
\end{abstract}

Keywords: Extrusion, pulse flour, expansion ratio, bulk density, hardness

The consumption of convenience foods is increasing rapidly because of improvement in economic conditions and demand of ready-to-eat, ready-to-cook and convenient mixes and its market is expanding fast in India. In recent years, consumers have developed a growing understanding of how the composition of food products has impact on the nutritional quality of food and health; good nutrition meant avoiding product with high calorie, salt and fat content (Brennan et al., 2008). One of the greatest challenges today is to develop inexpensive foods that are nutritionally superior and at the same time highly acceptable to intended consumer. Wheat is the world's most important and least expensive crop available for creating fabricating nutritious food. The quantity and diversity of enjoyable products made from wheat are variety of traditional products, baked products, extruded products, breakfast cereals etc.

Extrusion of foods is an emerging technology for the food industries to process and market a large number of products of varying sizes, shapes, texture and taste. Extrusion cooking is accomplished through the application of heat, either directly by steam injection or indirectly through jackets. It provides better mixing of raw materials as well as gives more flexibility to the product. Extrusion cooking helps in the removal of undesirable flavors and the other main functions are gelatinization of starch, denaturation of proteins and inactivation of enzymes. This process helps in destroying many toxins and antinutrients and also improves safety and digestion of food. It also helps in the more stability of minerals and other phenolic compounds. (Kaur et al., 2007). Extruded products i.e. pasta made from semolina are deficient in essential amino acids, lysine and threonine and devoid of fiber (Stephenson, 1983). Various protein sources have been used to fortify extruded products (Rayas et al., 1996; Wang et al., 1999). The legumes are not only rich in lysine content but are also considered a good source of complex carbohydrates, proteins, minerals and Bvitamins.

Grain legumes are considered to be good for health due to their mutual compatibility with cereals and for their properties in disease prevention, including cardiovascular disease, type- 2 diabetes, obesity and possibly colon cancer (Guillon and Champ, 2002). Soybean, a rich source of good nutritional quality, contains about $40 \%$ proteins and it can be effectively utilized for nutritional improvement of cereal-based extrudates (Kulkarni and Joshi, 1992). Among the grain legumes, green gram (Vigna radiata L.) is known for its easy digestibility, low flatulence potential and high protein content (Doughty and Walker, 1982). Greater attention is now being paid to the exploitation 
of less used pulses due to higher content of lysine (Singh et al., 1980).Legume seeds are second only to cereals as a source of human and animal food and these are also good source of protein, fiber and minerals. Cereals and legumes have been an integral part of most Indians because acid composition of legume and cereals are complementary (Duszkiewicz et al., 1988). Although legumes are the good source of nutrients but they also contain some antinutritional factors viz. phytic acid, polyphenols, trypsin inhibitors etc. These factors could be decreased or destroyed by appropriate processing (Grewal, 1992). Physical characteristics such as expansion, density, and hardness are important parameters to evaluate the consumer acceptability of the final product (Patil et al., 2007). Keeping these facts in view the present study was undertaken with the following objectives: To prepare value added extruded snacks by addition of pulses flour to wheat flour and maize grits andto study the physical and sensory characteristics of value added extruded snacks.

\section{Materials and methods}

Procurement of materials: Wheat variety (WH-912), soybean (PK-416) and green gram (Basanti) were procured from Department of Plant Breeding, CCS Haryana Agricultural University, Hisar. Maize was obtained from local market of Hisar. The wheat was cleaned for extraneous matter, immature and wrinkled seeds. The grains were conditioned to obtain $15 \%$ moisture and milled in Brabander Quardamat Junior Mill.

Extrudate preparation: The preliminary trials were conducted to prepare the snacks from the mix having different proportions of wheat flour and maize grits. The snacks prepared from 40:60 proportion of wheat flour and maize grits had the maximum expansion ratio.The ingredients were conditioned with $20 \%$ water and $1.5 \%$ salt and mixed to obtain homogenize mixture. The mixture was kept for 20 minutes at ambient temperature and remixed before extrusion. Further, for the purpose of value addition, $10 \%, 15 \%, 20 \%$ pulse flour (soybean and green gram) was replaced with the mixture of maize and wheat flour (60:40). The snacks were prepared by the replacement of wheat flour-maize grits mix with pulse flour (soybean and green gram) using twin screw extruder (BTPL lab model, Germany) where material was heated to $100-150^{\circ} \mathrm{C}$ temperature for $10-20 \mathrm{sec}$ and finally forced to the nozzle. The pressure at die nozzle varied from 20-40 atmospheres. The extrudates were cuts into pieces by the rotating cutter fixed at the nozzle and extrudates were collected in a trough. The temperature of the extruder was kept at $100-150^{\circ} \mathrm{C}$.

Chemical analysis: The wheat flour, maize grits and pulses flour viz. soybean and green gram were analyzed for proximate composition using standard method AOAC (1995).

Mineral Content: The samples were digested by wet digestion method. The iron and zinc were determined by Atomic Absorption Spectrophotometer (Lindsey and Norwell, 1969) in the Department of Soil Science, Haryana Agricultural University, Hisar. Calcium was estimated using standard method of AOAC (1995).

Total Dietary Fiber: The total dietary fiber was determined by slight modification of an enzymatic method using AOAC method (1995).

Physical and Textural properties of extrudates: Ready to eat extrudates were evaluated for their physical properties viz. expansion ratio, bulk density and texture (hardness). The expansion ratio was determined according to the method of Harper (1981). The bulk density was determined according to the method of Park et al., (1993). The texture of ready to extruded snacks prepared with or without incorporation of various levels of pulse flour was assessed using TATX plus Texture analyzer.

Sensory evaluation of extrudates: Extrudates were given auxiliary treatment with spice mixture. The auxiliary treated extrudates were evaluated for color and appearance, aroma, texture, taste using 9- point Hedonic scale by a panel of eight semi-trained judges. Average of the scores for all the sensory characteristics was expressed as over all acceptability score.

\section{Results and discussion}

Proximate composition of flours: Wheat flour, maize grits, pulse flour viz. soybean and green gram were assessed for proximate composition and results regarding moisture, crude protein, crude fat, ash, crude fibre, carbohydrate and energy $(\mathrm{kcal} / 100 \mathrm{~g})$ have been presented in Table 1.

Mineral content and total dietary fibre of flour: Wheat flour, maize grits, pulse flour viz. green gram and soybean were assessed for mineral content and total dietary fibre and data regarding these have been depicted in Table 2. The results regarding composition of wheat flour and pulse flour indicates that pulses 
contained appreciable amount of nutrients as compared to wheat flour and maize grits. As the pulses contain more calcium, iron, zinc and total dietary fiber than wheat flour and maize grits, so pulse flour can be incorporated to wheat and maize mixture for the purpose to increase fiber, ash, calcium, fat and total dietary fiber in wheat flour based food products. Among the two pulses studied soybean flour contained highest amount of protein, ash, crude fiber, fat, calcium, iron and total dietary fiber content. Similar results have been studied by Habib et al., 2005, Parvathi and Kumar, 2006, Sadana et al., 2006.

Physical characteristics and Texture of RTE-snacks: Ready-to-eat snacks, prepared from the incorporation of various levels of different pulse flour to the mixture of wheat flour and maize, were analyzed for physical parameters and data regarding expansion ratio, bulk density and hardness of RTE-Snacks has been presented in (Table-3). The expansion ratio, bulk density and hardness of RTE-Snacks without replacement (control sample) were 9.02, 0.06 and 5.17 $\mathrm{kg}$, respectively. A gradual decrease in expansion ratio and increase in bulk density and hardness of extrudates was noticed with every $5 \%$ increase in soybean flour in the formulation of RTE-Snacks. Similar trends were observed in the RTE-snacks prepared from green gram flour. Results indicate that higher the level of pulse flour in the RTE snacks lower is the expansion, higher is the bulk density and hardness. The lowering of expansion ratio (i.e. increase of bulk density and hardness) may be due to the decrease of corn starch in the mixtures and increase of protein and fiber concentration by the replacement of wheat-maize mix with pulse flour. Singh et al., (1996) has also reported an inverse relationship between expansion ratio and density of extrudates. The replacement of wheat-maize mix with pulse flour resulted in increase of protein content due to which the bulk density of extrudates increased. The formation of three-dimensional protein network by gluten proteins decreases starch swelling. Derby et al., (1975) also reported the reduced expansion of extrudate at die exit due to addition of protein to starch polymer. The extrudate hardness was strongly influenced by the protein content. Increased protein content in feed material produced more rigid network, resulting in higher resistance to shear. Similar results have been reported by Anton et al., (2009) for corn-starch based extruded snacks fortified with common beans (Phaseolus vulgaris) flour.

Sensory evaluation of RTE-snacks: The ready-to-eat snacks were analyzed for various sensory attributes viz. color and appearance, aroma, taste, texture and overall acceptability by using 9-point. The effect of wheatmaize flour mix replacement with pulse flour on quality of the product can be visually seen in the Fig. 1 and 2. Hedonic scale and results regarding these have been depicted Table 4. Sensory evaluation of RTESnacks showed that RTE-Snacks supplemented with $15 \%$ pulse flour were 'liked very much' by the judges. Further incorporation of pulse flour in the formulation decreased the mean scores for sensory attributes but those were comparable with control RTE-Snacks. The control RTE-Snacks and RTE-Snacks containing 15\% pulse flour were liked moderately to like very much. This indicates that up to $15 \%$ of wheat-maize mix can be replace with pulse flour without affecting the sensory attributes of snacks.

Table 1: Proximate composition and energy value of wheat flour, maize grits, soybean and green gram flour on g/100g dry matter basis

\begin{tabular}{|l|l|l|l|l|l|l|l|}
\hline Samples & Moisture & Protein & Fat & Ash & Crude fiber & $\begin{array}{l}\text { Carbo- } \\
\text { Hydrate }\end{array}$ & $\begin{array}{l}\text { Energy } \\
\text { (kcal/100g) }\end{array}$ \\
\hline Wheat flour & $11.8+0.28$ & $12.4+0.17$ & $0.89+0.07$ & $0.63+0.01$ & $0.37+0.2$ & $85.2+0.2$ & 394.00 \\
\hline Maize grits & $12.57 \pm 0.22$ & $7.35 \pm 0.03$ & $1.33 \pm 0.05$ & $0.63 \pm 0.07$ & $0.92 \pm 0.01$ & $89.7 \pm 0.07$ & 419.00 \\
\hline Soybean flour & $8.8+0.36$ & $37.35+0.27$ & $20.16+0.5$ & $4.66+0.02$ & $3.66+0.34$ & $34.14+1.22$ & 467.51 \\
\hline Green gram & $10.20+0.20$ & $21.25+0.29$ & $1.67+0.50$ & $3.53+0.15$ & $1.03+0.15$ & $72.52+0.17$ & 389.73 \\
\hline
\end{tabular}

Values are \pm S.D. of the three replicates 


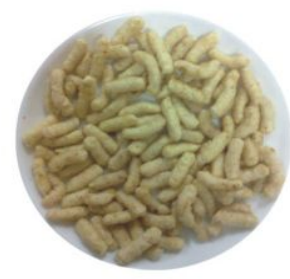

Control

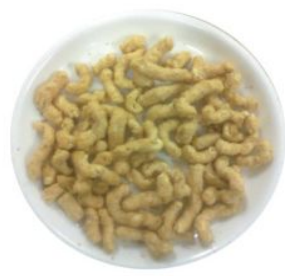

A

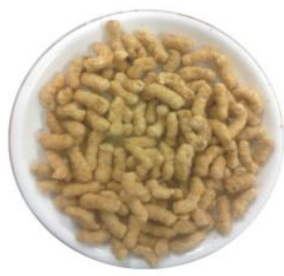

B

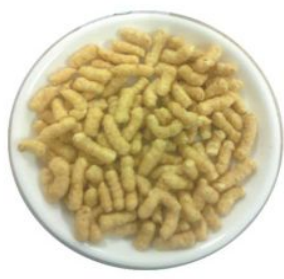

C

Fig. 1: RTE extruded snacks prepared by incorporation of 0 (control), 10(A), 15(B) and 20(C) percent of soybean flour

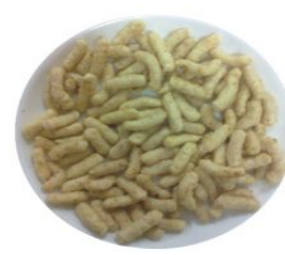

Control

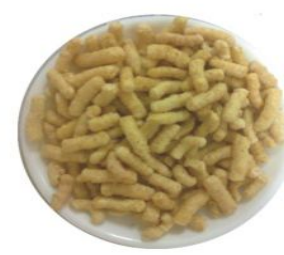

A

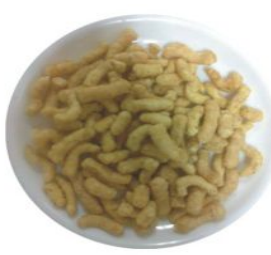

B

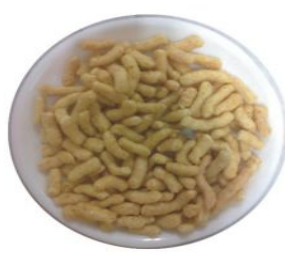

C

Fig. 2: RTE extruded snacks prepared by incorporation of 0(control), 10(A), 15(B) and 20(C) percent of green gram flour

Table 2: Mineral content and total dietary fiber of wheat flour, maize grits, soybean flour and green gram flour.

\begin{tabular}{|c|c|c|c|c|}
\hline Samples & Calciummg/100g) & Iron (mg/100g) & Zinc (mg/100g) & TDF (\%) \\
\hline Wheat flour & $17.0 \pm 0.6$ & $5.9 \pm 2.0$ & $1.5 \pm 0.4$ & $9.8 \pm 1.04$ \\
\hline Maize grits & $10.6 \pm 0.4$ & $4.4 \pm 0.5$ & $2.7 \pm 0.2$ & $10.1 \pm 0.9$ \\
\hline Soybean & $197.0 \pm 0.4$ & $11.0 \pm 0.21$ & $3.3 \pm 0.12$ & $18.3 \pm 0.1$ \\
\hline Greengram & $69.6 \pm 0.2$ & $4.7 \pm 0.4$ & $3.2 \pm 0.3$ & $11.8 \pm 0.02$ \\
\hline
\end{tabular}


Table 3: Effect of incorporation of different pulses flour on physical characteristics of ready to eat extruded snacks

\begin{tabular}{|c|c|c|c|c|}
\hline Sample & $\begin{array}{c}\text { Level of } \\
\text { Replacement (\%) }\end{array}$ & $\begin{array}{c}\text { Expansion } \\
\text { ratio }\end{array}$ & $\begin{array}{c}\text { Bulk density } \\
\left(\mathrm{g} / \mathrm{cm}^{3}\right)\end{array}$ & $\begin{array}{c}\text { Hardness } \\
(\mathrm{kg})\end{array}$ \\
\hline Soybean flour & $\begin{array}{c}0 \\
10 \\
15 \\
20\end{array}$ & $\begin{array}{l}9.02 \pm 0.01 \\
7.49 \pm 0.07 \\
6.43 \pm 0.01 \\
6.26 \pm 0.09\end{array}$ & $\begin{array}{l}0.06 \pm 0.00 \\
0.10 \pm 0.00 \\
0.14 \pm 0.00 \\
0.18 \pm 0.00\end{array}$ & $\begin{array}{l}5.17 \pm 0.05 \\
6.47 \pm 0.00 \\
6.56 \pm 0.01 \\
6.66 \pm 0.01\end{array}$ \\
\hline $\mathrm{CD}$ at $5 \%$ & & 0.203 & 0.005 & 0.090 \\
\hline $\begin{array}{l}\text { Green gram } \\
\text { flour }\end{array}$ & $\begin{array}{c}0 \\
10 \\
15 \\
20\end{array}$ & $\begin{array}{l}9.02 \pm 0.07 \\
8.84 \pm 0.01 \\
8.65 \pm 0.05 \\
8.17 \pm 0.10 \\
\end{array}$ & $\begin{array}{l}0.06 \pm 0.00 \\
0.07 \pm 0.00 \\
0.08 \pm 0.00 \\
0.08 \pm 0.00\end{array}$ & $\begin{array}{l}5.17 \pm 0.05 \\
5.22 \pm 0.01 \\
5.35 \pm 0.01 \\
5.48 \pm 0.04\end{array}$ \\
\hline CD at $5 \%$ & & 0.161 & 0.001 & 0.091 \\
\hline
\end{tabular}

Values are \pm S.D. of the three replicates

Table 4: Mean score for sensory characteristics of extruded snacks prepared by incorporating different pulse flours in wheat and maize grits

\begin{tabular}{|c|c|c|c|c|c|c|}
\hline Sample & $\begin{array}{c}\text { Level of } \\
\text { replacement(\%) }\end{array}$ & $\begin{array}{c}\text { Color and } \\
\text { Appearance }\end{array}$ & Taste & Aroma & Texture & $\begin{array}{c}\text { Over all } \\
\text { acceptability }\end{array}$ \\
\hline Soy bean & $\begin{array}{c}0 \\
10 \\
15 \\
20\end{array}$ & $\begin{array}{l}8.0 \pm 0.00 \\
8.2 \pm 0.21 \\
8.5 \pm 0.24 \\
8.5 \pm 0.22\end{array}$ & $\begin{array}{l}8.0 \pm 0.00 \\
8.5 \pm 0.22 \\
8.6 \pm 0.22 \\
8.2 \pm 0.17\end{array}$ & $\begin{array}{l}8.0 \pm 0.21 \\
8.3 \pm 0.21 \\
8.3 \pm 0.21 \\
8.3 \pm 0.21\end{array}$ & $\begin{array}{l}7.8 \pm 0.21 \\
7.6 \pm 0.21 \\
8.0 \pm 0.00 \\
8.0 \pm 0.00\end{array}$ & $\begin{array}{l}7.9 \pm 0.07 \\
7.9 \pm 0.07 \\
8.2 \pm 0.14 \\
8.2 \pm 0.13\end{array}$ \\
\hline CD at $5 \%$ & & N.S & N.S & N.S & N.S & N.S \\
\hline Green gram & $\begin{array}{c}0 \\
10 \\
15 \\
20\end{array}$ & $\begin{array}{l}8.0 \pm 0.00 \\
8.2 \pm 0.17 \\
8.2 \pm 0.17 \\
8.2 \pm 0.22\end{array}$ & $\begin{array}{l}8.0 \pm 0.00 \\
8.2 \pm 0.17 \\
8.0 \pm 0.00 \\
8.0 \pm 0.22\end{array}$ & $\begin{array}{l}8.0 \pm 0.21 \\
8.2 \pm 0.17 \\
8.0 \pm 0.20 \\
8.1 \pm 0.21\end{array}$ & $\begin{array}{l}7.8 \pm 0.21 \\
8.3 \pm 0.21 \\
8.0 \pm 0.26 \\
8.0 \pm 0.22\end{array}$ & $\begin{array}{l}7.9 \pm 0.07 \\
8.2 \pm 0.13 \\
8.4 \pm 0.18 \\
8.2 \pm 0.16\end{array}$ \\
\hline CD at $5 \%$ & & 0.32 & 0.44 & N.S & N.S & 0.38 \\
\hline
\end{tabular}

Values are \pm S.D. of the three replicates

\section{Conclusion}

Results indicate that pulses viz. soy bean and green gram can be processed to prepare flour, which can be utilized up to $15 \%$ for preparation of value added ready-to-eat (RTE) snacks with better physical characteristics and sensory attributes. The study has been shown the potential use of soy bean flour and green gram flour to develop the value added ready-to-eat (RTE) snacks.

\section{References}

1. Anton, A.A., Fulcher R.G. and Arntfied, S.D. (2009). Physical and nutritional impact of fortification of corn starch-based extruded snacks with common bean (Phaseolus vulgaris) flour: Effects of bean addition and extrusion cooking. Food Chem.113: 989-996.
2. AOAC (1995). Official methods of analysis $15^{\text {th }}$ Edn. Association of official Analytical Chemist Washing, D.C.

3. Brennan, M.A., Monro, J.A. and Brennen, C.S. (2008). Effect of inclusion of soluble and insoluble fibres into extruded breakfast cereal products made with reverse screw configuration. Intern. J. Food Sci. Technol.43: 2278-2288.

4. Derby, R.I., Miller, B.S., Miller, B.F. and Trimbo, H.B. (1975). Visual observation of wheat-starch gelatinization in limited water systems. Cereal Chem. 52: 702-713.

5. Doughty, J. and Walker, A. (1982). Las leguminosas en nutricionhumana. Organizacion de las Naciones Unidas para la 
Agricultura y la Alimentacion, Rome, Italie: FAO.

6. Guillon, F. and Champ, M.M.J. (2002). Carbohydrate fractions of legumes: uses in human nutrion and potential for health. Br. J. Nutr.88(3): S293-S306.

7. Duszkiewicz, R.W., Khan, K., Dick, J.W. and Holm, Y. (1988). Shelf life stability of spaghetti fortified with legume flours and protein concentrates. Cereal Chem.65(4): 278-88.

8. Grewal, R.B. (1992). Nutritional improvement of soybean through fermentation and its utilization in traditional foods in India. Ph.D. Thesis, CCS Haryana Agricultural University, Hisar, India.

9. Habib, F.G.K., Mahram, G.H., Hilal, S.H., Gabrial,G.N. and Morcos, S.R. (2005). Phytochemical and nutritional studies on pigeon pea and kidney bean cultivated in Egypt. J. Zeitschrift Swissens Chaft.15(2): 224-230.

10. Harper, J.M. (1981). Extrusion of food. Vols I and II, Boca Raton, Florida, CRC Press. USA.

11. Kaur, M., Pandey, H. and Mishra, H.N. (2007). Recent advances in food extrusion. Bev. Food World. 7: 46-49.

12. Kulkarni, S.D. and Joshi, K.C. (1992). Potato starch soy blends: possible effects of starch properties on few aspects of end products. Indian Food Packer. 66: 38-49.

13. Lindsey, W.L. and Norwell, M.A. (1969). A new DPTA-TEA soil test for zinc and iron. Agron. Absts.61: 84.

14. Patil, R.T., Berrios, J.D., Tang, J. and Swanson, B.G. (2007). Evaluation of methods for expansion properties of legume extrudates. Applied Engg. Agric. 23(6): 777-783.

15. Park, J., Rhee, K.S., Kim and Rhee, K.C. (1993). High protein texturized products of defatted soy flour corn starch and beef: shelf-life, physical and sensory properties. J. Food Sci.58: 21 27

16. Parvathi, S. and Kumar, V.J.F. (2006). Value added products from ricebean (Vigna umbellata). J. Food Sci Technol.43(2): 190193.

17. Rayas, D.P., Mock, C.M. and Satterlee, L.D. (1996). Quality of spaghetti containing buck-wheat, amaranth and lupin flours.Cereal Chem.73: 381-387.

18. Sadana, B., Hira, C.K., Singla, N. and Grewal, H. (2006). Nutritional evaluation of ricebean (Vigna umbellata) strains. J. Food Sci Technol.43(2): 190-193.

19. Singh, S.P., Chandel, K.P.S. and Pant, K.C. (1980). Major food constituents of ricebean (Vigna umbellata). J. Food Sci. Technol. 17: 23-26.

20. Singh, N., Singh, B., Sandhu, K.S., Bawa, A.S. and Sekhon, K.S. (1996). Extrusion behavior of wheat, rice and potato blends. J. Food Sci. Technol.31: 291-294.

21. Stephenson, C. (1983). World's best pasta. Macaroni J.65: 4-8.

22. Wang, J., Rossel, C.M and Barber. (2002) Effect of addition of different fibres on wheat dough performance and bread quality. Food Chem. 79: 221-26 